\title{
CJLT

\section{Screen capture technology: A digital window into students' writing processes Technologie de capture d'écran: une fenêtre numérique sur le processus d'écriture des étudiants}

Jeremie Seror, University of Ottawa

\begin{abstract}
Technological innovations and the prevalence of the computer as a means of producing and engaging with texts have dramatically transformed how literacy is defined and developed in modern society. This rise in digital writing practices has led to a growing number of tools and methods that can be used to explore second language (L2) writing development. This paper provides an overview of one such technique: the contributions of screen capture technology as a means of analyzing writers' composition processes. This paper emphasizes the unique advantages of being able to unobtrusively gather, store and replay what have traditionally remained hidden sequences of events at the heart of L2 writers' text production. Drawing on research data from case studies of university L2 writers, findings underscore the contribution screen capture technology can make to writing theory's understanding of the complex series of behaviours and strategies at the heart of L2 writers' interactions.
\end{abstract}

\section{Résumé}

Les innovations technologiques et la prévalence de l'ordinateur comme moyen de produire et d'interagir avec les textes ont radicalement transformé la façon dont la littératie est définie et développée dans la société moderne. Cette augmentation des pratiques d'écriture numérique a généré un nombre croissant d'outils et de méthodes disponibles pour explorer le développement de l'écriture dans une langue seconde (L2). Cet article donne un aperçu de l'une de ces techniques: les contributions offertes par la technologie de capture d'écran en tant que moyen d'analyse des processus d'écriture. L'article met l'accent sur les avantages incomparables qu'offre la possibilité de recueillir discrètement, de conserver et de revoir ce qui normalement reste une suite d'événements cachés au cœur du processus d'écriture dans une langue seconde. S'appuyant sur des données de recherche issues d'études de cas d'étudiants en L2 de niveau universitaire, les résultats mettent en lumière la contribution de la technologie de capture d'écran à la compréhension théorique de séries complexes de comportements et de stratégies situées au cœur des interactions des étudiants de L2 en contexte d'écriture. 


\section{Introduction}

Over the last decades, a growing body of research has focused on second language (L2) writers (Hinkel, 2010; P. K. Matsuda, Ortmeier-Hooper, \& A. Matsuda, 2009). This research reflects a growing awareness of a system-wide increase of students pursuing studies in a language other than their mother tongue (Canagarajah \& Jerskey, 2009) and of the necessity to rethink literacy practices and policies to address the needs of L2 writers (CCCC Committee on Second Language Writing, 2009). Drawing and expanding on work conducted on L1 writing development, this work has helped establish a more theoretically and empirically grounded account of L2 writers and their texts (Hinkel, 2010; Silva, 1997) and has led to important curricular and institutional guidelines regarding topics such as the design of effective writing centers for L2 writers (Williams, 2004), the potential impact of written feedback on writing development (Hyland, 2010; Séror, 2009, 2011) and detailed descriptions of the morphosyntactic and lexical features of L2 writers' texts (Hinkel, 2002).

Despite these advances, a number of facets of L2 writing remain to be more fully addressed (Hinkel, 2010). One such area concerns the investigation of L2 writers' strategies and composition processes. Whereas the cognitively demanding nature of learning to write in a second language has long been recognized, work in this area has predominantly drawn on research and models derived from studies of L1 writers. This work has led to important comparisons and attempts to link L1 and L2 writing processes (El-daly, 2012; Roca de Larios, Murphy, \& Marin, 2002). However, as noted by Belcher (2006) the focus in studies of L2 writers learning to acquire academic and professional genres has generally been on "products rather than processes" (p. 149). As a result, despite the considerable attention it has received another disciplinary areas, metacognition is a concept that has yet to be "sufficiently discussed in the context of L2 reading and writing" (Negretti \& Kuteeva, 2011, p. 95). Indeed, fine-grained analyses of the less tangible but nevertheless crucial series of steps taken by L2 students as they compose their texts are according to Petric and Czárl (2003) "somewhat of a latecomer in the field" (p. 188) and remain in comparison to other dimensions of L2 writing research relatively rare (El-daly, 2012; Leki, Cumming, \& Silva, 2008; Murphy \& Roca de Larios, 2010).

As such, although it has long been recognized that a writer's mastery of composition processes such as planning, formulating and revising is key to the success or failure of the texts he or she produces (Flower \& Hayes, 1981; Raimes, 1985), investigations of what L2 writers actually do when they sit to write, especially when these descriptions are situated within authentic writing contexts, represent an important area of research (Spelman Miller, 2005). In particular, by focusing on the link between writing processes and strategies as they occur in real world use, in moments of situated cognition (Kissinger, 2013), this work contributes to a more complete understanding of how L2 students master advanced literacy and textual meaning-making skills (Coker \& Lewis, 2008; Negretti \& Kuteeva, 2011; Roca de Larios, Manchón, Murphy, \& Marín, 2008; Victori, 1999).

\section{Researching L2 writers' composition processes}

Traditionally, researchers interested in L2 writers' composition processes have drawn on a combination of direct observations of writers and recounts produced by students about how they write (Miller, Lindgren, \& Sullivan, 2008; Pennington \& So, 1993). These methods have frequently included the use of think-aloud protocols (Cumming, 1990), retrospective interviews 
(Sasaki, 2000), process logs (Li \& Akahori, 2007), as well as direct and video- based observations of students (Sasaki, 2004). These approaches have been used to explore L2 writers' problem-solving processes (Manchón \& Larios, 2007) and to identify the strategies and behaviours displayed by different types of writers (e.g., strong versus weak, L1 students versus L2 students) (Bloom, 2008; Petrić \& Czárl, 2003).

While these approaches have had an important impact for the understanding of the strategies and skills that can be modeled and practiced with L2 students in classroom settings to promote writing success, the emergence of the computer as a digital writing tool has also resulted in the development of new methodologies based on on-line observations of students' actions as they compose on their computers (Barbier \& Spinelli-Jullien, 2009). Whether it be in the form of keyboard logging software (Miller, Lindgren, \& Sullivan, 2008), screen capture technology (Geisler \& Slattery, 2007), eye tracking technology (Wengelin et al., 2009) or software specifically designed to capture both keyboard and on screen events (Van Waes \& Leijten, 2006), these tools have opened up new terrains by producing rich, moment-to-moment records of students' composition processes (Barbier \& Spinelli-Jullien, 2009).

Often running invisibly on a computer as students write, these techniques stand in contrast to more obtrusive and reactive approaches like think-aloud protocols (Janssen, Van Waes, \& Van den Bergh, 1996) and have helped reduce disruptions to students' regular writing behavior thereby enhancing the ecological validity of the data observed (Van Waes, Leijten, \& van Weijen, 2009). Likewise, by providing empirical records of students' activities as they write on computers, these techniques offer valuable insights about emerging digital literacy practices in a world that is increasingly multimodal and situated in both physical and online spaces (Lea \& Jones, 2011).

Illustrative examples of the application of these online observation techniques include the work Macgilchrist and Van Hout (2011) who draw on screen video recordings and keystroke logs to gather data on the journalism practices of reporters composing articles on computers. They note the advantages of these tools as a way to produce a form of "computer-assisted ethnographic discourse analysis" (para. 3) that can lend new perspectives on questions of situated text production and the links between broader macro discourses and specific micro-level elements associated to writing as a situated practice. Similarly, Van Waes et al. (2009) used the logging program Inputlog to produced detailed descriptions of novice and professional writers as well as comparisons of L1 and L2 writers. They also stress the benefits of an approach that "made it possible to analyse on-line writing processes in L1 and L2 in far greater detail than was previously possible" (p. 51-52) thus allowing them to describe L2 writers' range of writing behaviours and to link these to the cognitive demands of L2 writing.

To better illustrate the potential stemming from these new approaches to L2 writing research, I briefly report below on findings taken from an ongoing study of L2 writers that has employed screen capture technology as a central component of its data collection. It is argued that screen capture technology represents a unique opportunity to study students' engagement with texts outside of the classroom context, a domain that has been typically difficult to access and observe by researchers, while also adding to our understanding of the unique processes and strategies associated to writing in digital spaces (Leon \& Pigg, 2011). 


\section{Using screen capture to study writing processes: Study description}

This paper draws on an ongoing two-year project focusing on the composition processes and strategies of university students learning to write in their second language. The study, motivated in part by my own experiences as a language teacher working in university contexts with novice and advanced L2 writers, draws on a case study design (Duff, 2008) and focuses on the composition processes of L2 university writers captured through the use of digital recordings of these students' on-screen actions as they complete writing assignments on computers for their classes in naturalistic settings.

The recruited participants for this project stem from regular, credit-bearing semester-long French second language writing classes and English second language writing classes offered at a large Canadian university. Following a brief presentation by the researcher in students' classes at the beginning of the semester, interested students sign informed consent forms to participate in the study and work closely with researcher to discuss the project, its objectives and the nature of the writing tasks they might want to record.

To produce these visual records students are introduced to the "PRO" version of the screen capture tool: Screencast-O-Matic (http://screencast-o-matic.com/). This web-based application, is part of a growing number of programs designed to create digital screen recordings, with or without audio recorded comments, which can then be shared with others. Also known as screencasting technology, these programs have been used by software developers, gamers, librarians and educators to produce and distribute videos of themselves completing various tasks on computers (Carr \& Ly, 2009; Seror, 2012). ${ }^{1}$ Screencast-O-matic is but one of a growing number of software options presently available to produce screen capture videos. It has, however, been identified as one of the better available programs offering a "highly recommended", "easy to use tool" (Harrell, 2012, p. 63). In the case of this study, Screencast-Omatic was chosen after an extensive period of exploring and testing a variety of screen capture options. ${ }^{2}$ Its selection was guided in large part by the observed reliability of the tool, the simplicity of its interface as well as its unique advantage as a web-based program that does not require participants to download and install software on their individual computers. Instead, using a password protected web address, students can use java-based controls to produce recordings of unlimited duration of their on-screen activities on any computer they may find themselves working on.

Once trained to use Screencast-O-matic, participants are invited to record themselves at moments of their choosing as they complete writing assignments for their writing class. Students are also allowed, should they ask to do so, to record second language writing completed for other courses or activities (ex. one student recorded herself as she composed a text in her L2 for a local university student association).

\footnotetext{
${ }^{1}$ Many of the video tutorials and walkthroughs posted on social media sites such as YouTube to help individuals master specific computer skills or programs are produced with screen capture technology.

${ }^{2}$ Both Peterson (2007) and Carr and Ly (2009) offer excellent reviews of the emergence of screencasting tools and descriptions of some of the various options available to educators.
} 
The decision to allow students the flexibility to choose what and when to record was made to ensure students remained comfortable and in full control of the data collection process. This was deemed an important ethical element to include in the design of the study since students are asked to record and share writing behaviour that occurs in the great majority of cases outside of the classroom, on their own personal computers and in locations closely associated to their private lives.

At the time of writing this article, a total of 11 students had been recruited for this study each producing at least one recording of a writing session. In most cases, students shared recordings of themselves completing a short class writing assignment from beginning to end. Some students, however, also submitted recordings of themselves working on various segments of longer texts (ex. working on the chapter of a thesis or an essay produced in content course taken in their second language).

Supplementing the recordings produced by students, additional data collected for the study included questionnaires about students' writing backgrounds and writing processes, semi-formal interviews with participants, field notes, as well as the examination of students' final drafts and/or any relevant documents related to the writing sessions recorded (i.e., assignment descriptions, hand written notes or outlines produced by the student prior to sitting down at their computer).

These various sources were triangulated to enhance and corroborate the validity of the interpretations drawn from the data (DuFon, 2002). The interviews in particular, provided valuable insights by allowing students to discuss the rationales and forces they felt motivated particular events and processes observed in the visual records of their writing behaviour. The semi-formal interview questions focused on a) students' prior experiences as writers, b) contextual information about the assignments recorded and c) explorations of specific moments identified in the videos by reviewing these with student and discussing their reasoning and feelings about what could be observed in their composition processes.

Data analysis procedures were guided by the following three research questions: 1) What are the identifiable features that characterize the writing processes and strategies observable in the visual records of L2 learners learning to write for university courses? 2) How are these features explained and understood by the L2 learners who enact them? 3) What are the implications of these features and their explanations by students for L2 writing theory and pedagogy?

To facilitate the complex process of sifting through the wealth of data collected for this study, Morae Manager was chosen as an analytical tool to code and explore patterns of events within the recordings of students writing processes. Originally designed for usability testing of software, Morae has been identified as "a promising observation tool for educational research" that can be used for both quantitative and qualitative analysis of audiovisual data (Asselin \& Moayeri, 2010, p. 43). Morae was used to tag various screen events in students' recordings including, amongst others, pauses of more than a second in length, mouse movements, periods of text generation (moments when a student is typing and producing text with no pauses of more than a second interrupting the writing flow), students use of Internet sources, and revision events. 


\section{Rich findings: Examples of the insights made possible by screen capture data}

The video records produced by students as part of this study make up a rich data set that is open to a variety of levels of analysis. At one level, the detailed logs of students' writing processes produced through Morae make it possible to produce descriptive statistics regarding the frequency and duration of specific events in students' writing sessions. These descriptive statistics can be used in collaboration with the student interviews and questionnaires to establish more comprehensive portraits of each student. One can calculate, for example, how much time is spent engaging in various activities as a percentage of the overall recording time. Additional elements that can be measured also include the frequency and duration of text generation events, pauses as well as students' use of external Internet sources or their L1.

As such, it is possible, for example, to compare two participants who completed as part of the same writing course identical assignments: a paragraph-long written summary of an audiorecorded interview available on the Internet (see Table 1). The descriptive statistics reveal two very different types of writers. An analysis of the duration of pauses and moments of text generation allow us to note that participant 2 not only wrote more, but also spent close to twice as much time proportionally actually generating text with longer episodes of text generation on average and a smaller proportion of her total time spent pausing. Participant 1, on the other hand, appears to have been, for this particular assignment, less fluent as a writer with a greater number of pauses and a smaller proportion of time spent generating text. An analysis of the amount of time students spent drawing on Internet resources also signals participant 1's apparent difficulties with the writing task as she can be seen to have devoted more time referring to external Internet resources (online dictionaries, translation websites, and online grammar checkers) to help her produce her text than participant 2.

Table 1: Writing session statistics for participants 1 and 2 - Interview summary task

\begin{tabular}{|l|c|c|}
\hline & Participant 1 & Participant 2 \\
\hline Length of writing session & 42.9 minutes & 74.42 minutes \\
\hline Number of words produced & 251 words & 758 words \\
\hline $\begin{array}{l}\text { Number of separate events coded in the writing } \\
\text { session }\end{array}$ & 1034 & 1616 \\
\hline $\begin{array}{l}\text { Time spent generating text a percentage of the total } \\
\text { time spent writing }\end{array}$ & $13 \%$ & $30 \%$ \\
\hline Average text generation period length & 2.44 seconds & 5.43 seconds \\
\hline $\begin{array}{l}\text { Time spent pausing as a percentage of total time } \\
\text { spent writing }\end{array}$ & $46 \%$ & $31 \%$ \\
\hline Average pause length & $5.54 \mathrm{~s}$ & $5.05 \mathrm{~s}$ \\
\hline $\begin{array}{l}\text { Time spent using Internet resources as a percentage } \\
\text { of the total time spent writing }\end{array}$ & $25 \%$ & $8.5 \%$ \\
\hline
\end{tabular}


The data generated from the quantitative analysis of students' writing sessions can also be used to track the distribution of various activities over the span of a writing session. For example, it is possible to see in the graph below that for participant 2 the use of external sources on the Internet (Reverso.net) is found exclusively in the second half of the writing session.

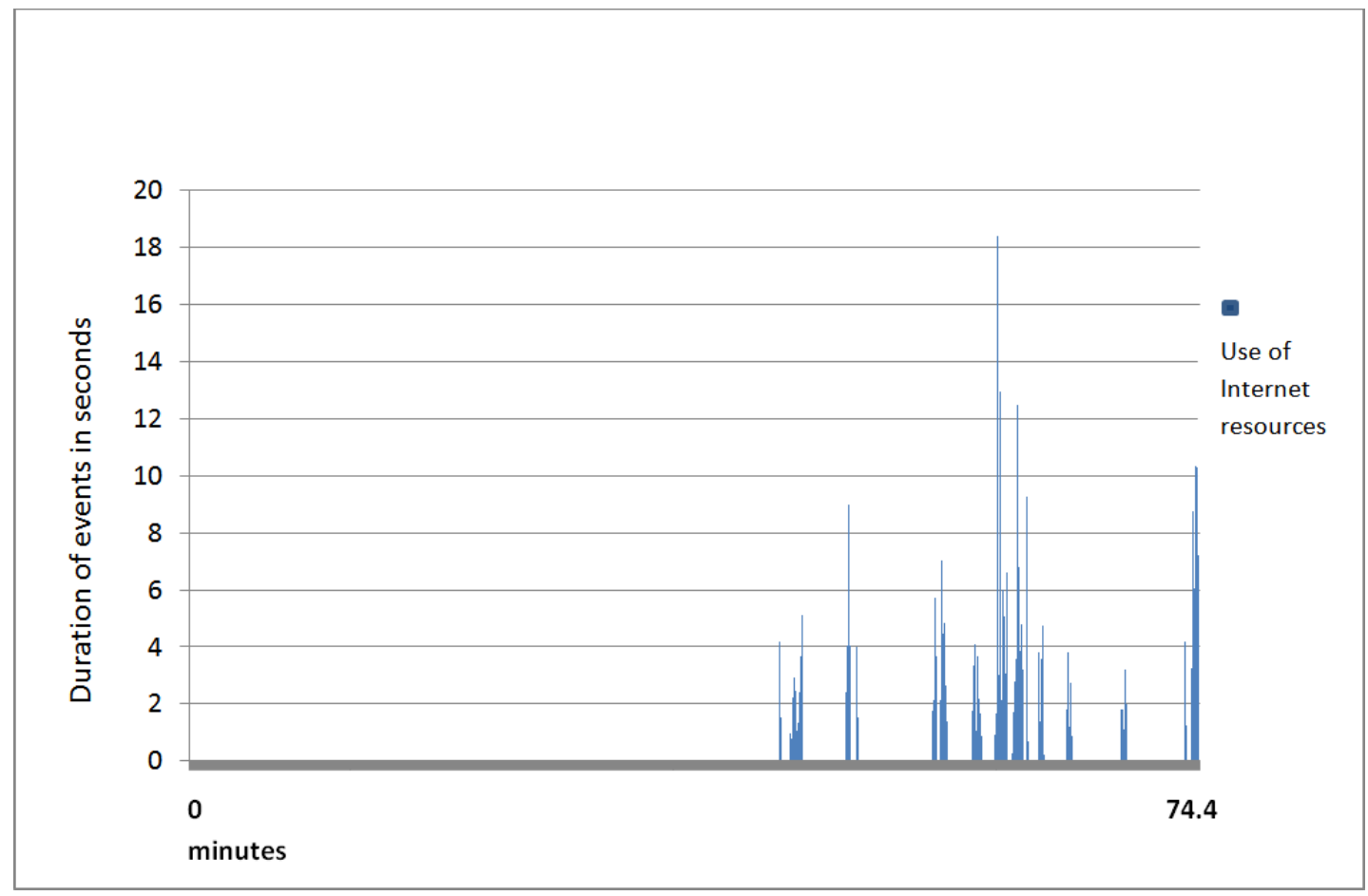

Figure 1: Participant 2: Distribution of episodes of turning to Internet resources

In the case of participant 1, the use of external Internet resources begins earlier in the writing session although there is a similar clustering of these events near the end of the writing session with, in particular, the regular use of the online grammar and spell checker BonPatron.com in the second part of the writing session.

Both of these cases, illustrate how screen capture technology allows researchers to gain a better sense of not only the resources that students draw on but also at what stage of the writing session these resources are more likely to appear (i.e., in the case of these two writers a heavier reliance on Internet resources is seen in the final revision stages of composing a text).

The most interesting insights emerging from this data, however, stem from the ability to engage in detailed microanalysis of specific moments of interest in a writing session. Drawing on Park's (2010) notion of transactions as a unit of analysis for the study of writing processes, it is possible to identify and examine moments in the recordings where there is visual evidence of a writer experiencing a problem followed by their attempts to resolve this problem. Analyzing in this way the sequential nature of specific composition processes and strategies with the help of the visual information provided by the recordings, one can investigate the interactions and relationships between various events by asking the same question made famous in the microanalytic techniques of conversation analysis: "Why this now?" (Box, 2012). 


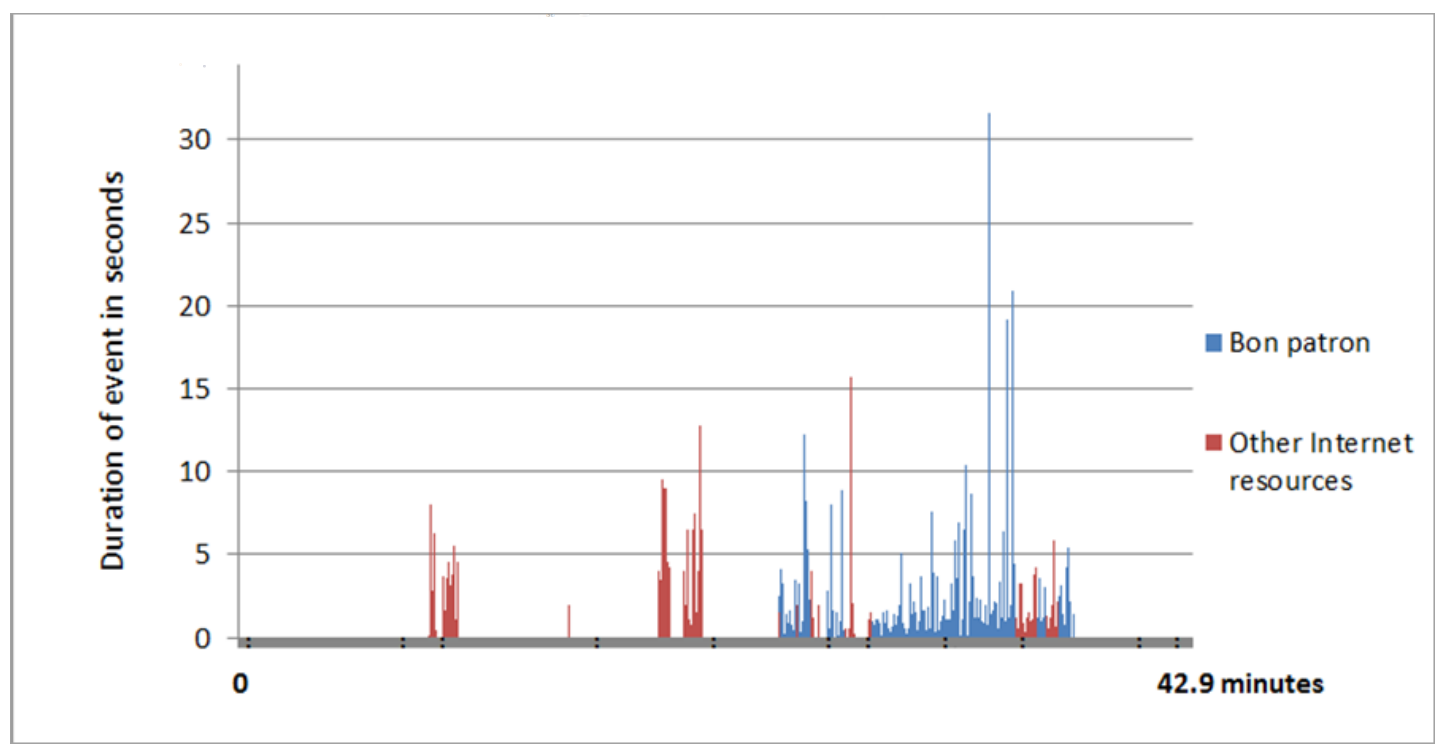

\section{Figure 2: Participant 1: Distribution of episodes of turning to Internet resources}

For instance, in the data excerpt below, focusing on what occurs before and after a significant pause in the student's writing to determine the cause of the interruption in text generation illuminates the impact spellcheckers can have on students' overall fluency as they write. Indeed, whereas many writing handbooks suggest that students should be encouraged to write first and edit later to reduce the cognitive complexity of trying to focus simultaneously on generating text and editing (Elbow, 1998; Goodson, 2012), a common pattern emerging from the data was a stop and go approach with L2 students editing themselves very much as they went along. This pattern reflects the disruptive nature noted in the literature of the linguistic challenges experienced by L2 writer as they struggle with a lack of automaticity at various levels including lexical choice, grammatical structuring or even spelling (McCutchen, 2000). In what follows (see Table 2), one can note this disruptive pattern and its links to the appearance of Microsoft's red squiggly line as a flag for students that they have misspelled a word.

After misspelling the name "Christiane", we find an initial pause of 1.26 seconds, followed by another pause of 4.45 seconds after the appearance of a red line. The combined above average pause length of 6.36 seconds signals the student's difficulty with the spelling of this word ("Christaine" versus "Christiane") and apparent inability to resolve this problem quickly (a pattern repeated at other times in the text). Ultimately, the decision is made to simply move on with the writing only to have the writing be once again interrupted by the signalling of another spelling mistake by the program. This time, however, the mistake appears less problematic as indicated by the shorter pause and immediate self-correction. The disturbance in the writing process however remains significant enough that the student chooses first too save her document (a text external process) before moving on and getting back to text generation.

The emergence of this type of pattern of events raises interesting questions about the potential advantage of teaching students to turn off their spell checkers while they compose their first drafts as a way to minimize potential sources of interruption and distractions while writing. Moreover, by showing that the generation of six words ("Christiane donne des exemples de notre") involves close to half of minute of work and numerous steps involving experiments and 
choices unique to this writer, this type of microanalysis helps to draw attention to the complexity and recursive nature of the multiple set of practices that make up writing (Galbraith, Van Waes, \& Torrance, 2007). Step-by-step, one can see the effort, time, and trial and error that underlie students' actions as they write, including amongst others: stopping, revising, researching, making choices, validating their choices, and pausing, all before writing again.

Table 2: Time-log of on-screen events

\begin{tabular}{|c|c|c|c|}
\hline $\begin{array}{l}\text { Time } \\
\text { code }\end{array}$ & Event & $\begin{array}{c}\text { Text } \\
\text { Produced }\end{array}$ & $\begin{array}{c}\text { Duration of } \\
\text { Event in Seconds }\end{array}$ \\
\hline $02: 05.9$ & Student generates text & "Christaine" & 1.26 \\
\hline $02: 07.2$ & Pause & & 1.93 \\
\hline 02:09.2 & $\begin{array}{l}\text { MS WORD indicates a spelling error after } \\
\text { student moves cursor forward }\end{array}$ & & \\
\hline 02:09.2 & Pause & & 4.43 \\
\hline $02: 13.6$ & Starts to generate text & $\begin{array}{l}\text { "donne des } \\
\text { exampke" }\end{array}$ & 4.45 \\
\hline $02: 18.1$ & Immediately corrects the sentence & $\begin{array}{l}\text { "donne de } \\
\text { examples" }\end{array}$ & 1.56 \\
\hline $02: 19.7$ & $\begin{array}{l}\text { MS WORD indicates a spelling error after } \\
\text { student moves cursor forward }\end{array}$ & & \\
\hline $02: 09.2$ & Pause & & 2.8 \\
\hline $02: 22.5$ & Student moves mouse & & 1.63 \\
\hline $02: 24.3$ & Clicks on misspelled word & & \\
\hline $02: 25.2$ & Corrects the word & $\begin{array}{c}\text { "des } \\
\text { exemples" }\end{array}$ & 0.26 \\
\hline $02: 25.5$ & $\begin{array}{l}\text { Moves mouse and clicks at the end of the } \\
\text { word to end of word and clicks }\end{array}$ & & 0.8 \\
\hline $02: 27.4$ & Saves her document & & 0.73 \\
\hline $02: 28.2$ & Moves mouse & & 1.86 \\
\hline $02: 30.0$ & Pause & & 3.06 \\
\hline $02: 33.0$ & Generates text & "de notre" & 1.46 \\
\hline $02: 34.6$ & Pause & & 2.46 \\
\hline
\end{tabular}

Amongst these various processes, a fascinating aspect of this data is the ability to watch students interact on screen not only with their texts, but also with the wide range of tools available in a digital and web-based learning environments -- all participants in the study to date wrote while connected to the Internet. Online dictionaries, thesauruses, translation sites, search engines, audiovisual media, and the use of online forums, all coexist in these videos with the computer screen serving as the stage where these resources meet and interact.

Of similar interest are instances when students' use their L1 to mediate the linguistic challenges of writing in L2. This pattern confirms findings in the literature concerning the role L1 use can play for L2 writing (Stapa \& Majid, 2012) and highlights how writing in a digital environment 
can enhance opportunities for students to draw on their L1 to confirm the appropriateness of candidate words or phrases thanks to online bilingual dictionaries and translation sites.

Again, it is noteworthy that L1 use is an example of a dimension of students' writing processes, which in the majority of cases become invisible in the final draft L2 writers submit. Indeed, while a final copy of a text handed in for marks does contain clues about the processes potentially involved in the creation of a text (i.e., how much time and care was spent revising), much remains hidden about how a text was generated even when this information may in fact have a great deal to tell us about the writer and their L2 proficiency. For example, it is only by watching one of participant's screen capture video that one can see that her one page French assignment was originally fully drafted in English only to be later translated, phrase by phrase, into French in the second half of her writing session.

Finally, screen capture data helps illustrate the fluid and transitory nature of writing processes. In contrast to approaches which, as argued Barbier and Spinelli-Jullien (2009), have traditionally characterized writing processes as static entities, these empirical records of students writing in real time offer instances of students adapting and modifying within the span of a single writing session their uses of specific strategies or processes.

For instance, participant 1 at the start of the revision stage of her writing session began to make use of a web-based French spell and grammar checker (BonPatron) to revise her text. After copying her draft into the BonPatron browser window from the Microsoft Word window she had been working in, the student initially started to revise her text by moving back and forth between the BonPatron website and her Word document as she made changes in response to the suggestions found on the BonPatron website. Of note is that midway through this process, the participant came to realize that she could simplify the revision process by editing her text directly on the BonPatron page thus allowing her to concentrate on a single version of the text in a single window. Using this system, only once she had finished editing her text did she then need to copy-paste her modified text back into Microsoft Word to be able to save her work. This small but important change in her use of BonPatron not only increased the efficiency with which the student could revise, it is also illustrates how L2 writers' composition processes can evolve and change "in vivo" as students engage and experiment with them as they write. These findings reinforce arguments in favour of viewing each writing moment as a site of struggle and experimentation, and thus of potential development with specific strategies and processes being developed, refined and transformed through experience and time (Park \& Kinginger, 2010).

\section{Discussion}

While these findings remain preliminary and subject to elaboration, this article has sought to briefly illustrate insights possible through the use of screen capture technology and its applications to the study of L2 writing processes and strategies.

It is argued that screen capture technology can produce powerful real-time visual records of the multiple events involved as students learn to write in digital spaces. When complemented with other traditional data sources, this methodology can thus help contribute to writing theory's understanding of the complex interactions of behaviours and strategies exhibited by L2 writers and can serve to break down popular but overly simplistic depictions of writing as a fixed homogeneous whole (Galbraith, Van Waes, \& Torrance, 2007). Indeed, screen capture 
technology represents a novel means of researching writing processes by allowing L 2 researchers to document learning processes and their associated tools (e.g., online dictionaries, task descriptions, spell checkers, online forums, amongst others) "in flight" and in context (Atkinson, Churchill, Nishino, \& Okada, 2007, p. 172). One is hence better equipped to produce situated descriptions of writing processes and to highlight the inseparable link between these processes and the environments and activities in which they are embedded.

Moreover, by producing detailed portraits of individual writers working on computers and their preferred strategies (ex. the degree to which errors are dealt with immediately or at a later stage) and key resources (ex. use of L1 and external web-based sources of information), this approach provides valuable data about digital literacy practices and the ways in which these are changing how a new generation of students are learning to write (Walker et al., 2011). Consequently, this type of research can help account for some of the fundamental changes associated to writing in digital environments (Grabill \& Pigg, 2010). This includes, for instance, the fact that for a new generation of students writing is no longer the solitary act it was once characterized as with signs that writing in digital spaces is now, perhaps more than ever, an activity where one finds surrounded and scaffolded by the texts, resources and voices of others.

By working to further develop our understanding of how second language is transformed by computers, it is anticipated that screen capture data will help establish for researchers, teachers and students new accounts and perspectives of L2 writers and the events and forces, both visible and invisible, that affect the decisions made by writers and the ultimate quality of the texts they produce. In so doing, this technology opens us new ways to capture, quite literally, a clearer and more dynamic picture of the relationships between texts, processes, strategies and resources used by L2 student and will contribute to a richer and more complete understanding of the processes at the heart of L2 writing development.

\section{Acknowledgements:}

The findings reported above are drawn from a larger study made possible through the support of an Insight Grant funded by the Social Science and Humanities Research Council of Canada. I am also grateful to the reviewers for their careful comments on earlier drafts of this article as well as Jessica Durepos and Fatima Assaf the two research assistants who have contributed to this project.

\section{References}

Abdel Latif, M. M. (2008). A state-of-the-art review of the real-time computer-aided study of the writing process. IJES, International Journal of English Studies, 8(1), 29-50.

Atkinson, D., Churchill, E., Nishino, T., \& Okada, H. (2007). Alignment and interaction in a sociocognitive approach to second language acquisition. The Modern Language Journal, 91(2), 169-188. 
Barbier, M. L., \& Spinelli-Jullien, N. (2009). On-line tools for investigating writing strategies in L2. German as a foreign language, 2(3), 23-40.

Belcher, D. (2006). English for specific purposes: Teaching to perceived needs and imagined futures in worlds of work, study, and everyday life. TESOL Quarterly, 40(1), 133-156.

Bloom, M. (2008). Second language composition in independent settings: Supporting the writing process with cognitive strategies. In S. Hurd \& T. Lewis (Eds.), Language learning strategies in independent settings (pp. 103-118). Clevedon: Multilingual Matters.

Bourgeois, D. (2011). Research on economic development and human resource development in official language minority communities. Assessment and prospects. Ottawa: Beaubassin Research Institute.

Box, C. (2012). Applying conversation analysis to real-world concerns. Teachers College, Columbia University Working Papers in TESOL \& Applied Linguistics, 12(1), i-iv; 35-54.

CCCC Committee on Second Language Writing. (2009, November). CCCC statement on second language writing and writers. Retrieved from http://www.ncte.org/cccc/resources/positions/secondlangwriting

Canagarajah, S., \& Jerskey, M. (2009). Meeting the needs of advanced multilingual writers. In R. Beard, D. Myhill, J. Riley \& M. Nystrand (Eds.), The SAGE handbook of writing development (pp. 472-488). Thousand Oaks, CA: Sage Publications.

Carr, A., \& Ly, P. (2009). "More than words": Screencasting as a reference tool. Reference Services Review, 37(4), 408-420.

Coker, D., \& Lewis, W. E. (2008). Beyond writing next: A discussion of writing research and instructional uncertainty. Harvard Educational Review, 78(1), 231-251.

Cumming, A. (1990). Metalinguistic and ideational thinking in second language composing. Written Communication, 7, 482-511.

Duff, P. (2008). Case study research in applied linguistics. New York: Lawrence Erlbaum Associates.

DuFon, M. A. (2002). Video recording in ethnographic SLA research: Some issues of validity in data collection. Language Learning \& Technology, 6(1), 40-59.

Elbow, P. (1998b). Writing without teachers (2 ${ }^{\text {nd }}$ ed.). New York: Oxford University.

El-daly, H. M. (2012). Linguistic, cognitive and cultural dimensions of the narrative written production of Arabic and Spanish speakers. International Journal of English Linguistics, 2(2), 49-74.

Flower, L., \& Hayes, J. R. (1981 ). A cognitive process theory of writing. College Composition and Communication, 32 365-387. 
Galbraith, D., Van Waes, L., \& Torrance, M. (2007). Introduction. In M. Torrance, L. Van Waes \& D. Galbraith (Eds.), Writing and cognition: Research and applications (Vol. 20, pp. 110). Amsterdam: Elsevier.

Geisler, C., \& Slattery, S. (2007). Capturing the activity of digital writing: Using, analyzing, and supplementing video screen capture. In H. A. McKee \& D. N. DeVoss (Eds.), Digital writing research: Technologies, methodologies, and ethical issues (pp. 185-200). Cresskill, N.J.: Hampton Press.

Goodson, P. (2012). Becoming an academic writer: 50 exercises for paced, productive, and powerful writing. Thousand Oaks, CA: Sage Publications.

Grabill, J., \& Pigg, S. (2010). The writing lives of college students. East Lansing, MI: Writing in Digital Environments Research Center.

Harrell, E. (2012). Screencast-o-matic: www.screencast-o-matic.com. Public Services Quarterly, $8(1), 62-63$.

Hinkel, E. (2002). Second language writer's text: Linguistic and rhetorical features. Mahwah, NJ: Lawrence Erlbaum Associates.

Hinkel, E. (2010). What research on second language writing tells us and what it doesn't. In E. Hinkel (Ed.), Handbook of Research in Second Language Teaching and Learning (Vol. 2, pp. 523-538). New York: Routledge.

Hyland, F. (2010). Future directions in feedback on second language writing: Overview and research agenda. IJES, International Journal of English Studies, 10(2), 171-182.

Janssen, D., Van Waes, L., \& Van den Bergh, H. (1996). Effects of thinking aloud on writing processes. In C. M. Levy \& S. Ransdell (Eds.), The science of writing (pp. 233-250). Mahwah, NJ: Erlbaum.

Kissinger, J. S. (2013). The social and mobile learning experiences of students using mobile ebooks. Journal of Asynchronous Learning Networks, 17(1), 171.

Lea, M. R., \& Jones, S. (2011). Digital literacies in higher education: Exploring textual and technological practice. Studies in Higher Education, 36(4), 377-393.

Leki, I., Cumming, A. H., \& Silva, T. (2008). A synthesis of research on second language writing in English. New York, NY: Routledge.

Leon, K., \& Pigg, S. (2011). Graduate students professionalizing in digital time/space: A view from "down below." Computers and Composition, 28(1), 3-13.

Li, K., \& Akahori, K. (2007). Development and evaluation of an online handwritten feedbackgiving support system in learning Japanese writing. The JALT CALL Journal, 3(3), 73-84.

Macgilchrist, F., \& Van Hout, T. (2011). Ethnographic discourse analysis and social science. Forum Qualitative Sozialforschung/Forum: Qualitative Social Research, 12(1). 
Manchón, R. M., \& Larios, J. R. d. (2007). On the temporal nature of planning in L1 and L2 composing. Language learning, 57(4), 549-593.

Matsuda, A., \& Matsuda, P. K. (2010). World Englishes and the teaching of writing. TESOL Quarterly, 44(2), 369-374.

Matsuda, P. K., Ortmeier-Hooper, C., \& Matsuda, A. (2009). The expansion of second language writing. In R. Beard, J. Riley, D. Myhill \& M. Nystrand (Eds.), Sage handbook of writing development (pp. 457-471). Thousand Oaks, CA: Sage Publications.

McCutchen, D. (2000). Knowledge, processing, and working memory: Implications for a theory of writing. Educational Psychologist, 35(1), 13-23.

Miller, K. S., Lindgren, E., \& Sullivan, K. P. H. (2008). The psycholinguistic dimension in second language writing: Opportunities for research and pedagogy using computer keystroke logging TESOL Quarterly, 42(3), 433-454.

Murphy, L., \& Roca de Larios, J. (2010). Searching for words: One strategic use of the mother tongue by advanced Spanish EFL writers. Journal of Second Language Writing, 19(2), 6181.

Negretti, R., \& Kuteeva, M. (2011). Fostering metacognitive genre awareness in L2 academic reading and writing: A case study of pre-service English teachers. Journal of Second Language Writing, 20(2), 95-110.

Park, K., \& Kinginger, C. (2010). Writing/thinking in real time: Digital video and corpus query analysis. Language Learning \& Technology, 14(3), 31-50.

Pennington, M., \& So, S. (1993). Comparing writing process and product across two languages: A study of 6 Singaporean university student writers. Journal of Second Language Writing, $2,41-63$.

Peterson, E. (2007). Incorporating screencasts in online teaching. The International Review of Research in Open and Distance Learning, 8(3).

Petrić, B., \& Czárl, B. (2003). Validating a writing strategy questionnaire. System, 31(2), 187215.

Raimes, A. (1985). What unskilled ESL students do as they write: A classroom study of composing. TESOL Quarterly, 19(2), 229-258.

Roca de Larios, J., Manchón, R., Murphy, L., \& Marín, J. (2008). The foreign language writer's strategic behaviour in the allocation of time to writing processes. Journal of Second Language Writing, 17(1), 30-47.

Roca de Larios, J., Murphy, L., \& Marin, J. (2002). Critical examination of L2 writing process research. In S. Ransdell \& M.-L. Barbier (Eds.), New directions for research in L2 writing (Studies in Writing: Vol. 11, pp. 49-80). Dordrecht: Kluwer Academic Publishers. 
Sasaki, M. (2000). Toward an empirical model of EFL writing processes: An exploratory study. Journal of Second Language Writing, 9(3), 259-291.

Sasaki, M. (2004). A multiple-data analysis of the 3.5-year development of EFL student writers. Language Learning, 54(3), 525-582.

Seror, J. (2009). Institutional forces and L2 writing feedback in higher education. Canadian Modern Language Review, 66(2), 203-232.

Seror, J. (2011). Alternative sources of feedback and second language writing development in university content courses. Canadian Journal of Applied Linguistics (CJAL)/Revue canadienne de linguistique appliquée (RCLA), 14(1), 118-143.

Seror, J. (2012). Show me! Enhanced feedback through screencasting technology. TESL Canada Journal, 30(1), 104-116.

Silva, T. (1997). On the ethical treatment of ESL writers. TESOL Quarterly, 31(2), 359-363.

Spelman Miller, K. (2005). Second language writing research and pedagogy: A role for computer logging? Computers and Composition, 22(3), 297-317.

Stapa, S. H., \& Majid, A. H. A. (2012). The use of first language in developing ideas in second language writing. American Journal of Social Issues \& Humanities, 2(3), 148-151.

Stapleton, P. (2010). Writing in an electronic age: A case study of L2 composing processes. Journal of English for Academic Purposes, 9(4), 295-307.

Unsworth, L. (2006). Towards a metalanguage for multiliteracies education: Describing the meaning-making resources of language-image interaction. English Teaching: Practice and Critique, 5(1), 76.

Van Waes, L., \& Leijten, M. (2006). Logging writing processes with Inputlog. In L. Van Waes, M. Leijten, C. M. Neuwirth \& G. Rijlaarsdam (Eds.), Studies in Writing. Vol. 17. Writing and digital media (pp. 158-165). Oxford: Elsevier.

Van Waes, L., Leijten, M., \& van Weijen, D. (2009). Keystroke logging in writing research: Observing writing processes with Inputlog. GFL-German as a foreign language, 2(3), 4164.

Victori, M. (1999). An analysis of writing knowledge in EFL composing: A case study of two effective and two less effective writers. System, 27(4), 537-555.

Walker, J. R., Blair, K. L., Eyman, D., Hart-Davidson, B., McLeod, M., Grabill, J., et al. (2011). Computers and Composition 20/20: A Conversation Piece, or What Some Very Smart People Have to Say about the Future. Computers and Composition, 28(4), 327-346.

Wengelin, Å., Torrance, M., Holmqvist, K., Simpson, S., Galbraith, D., Johansson, V., et al. (2009). Combined eyetracking and keystroke-logging methods for studying cognitive processes in text production. Behavior research methods, 41(2), 337. 
Williams, J. (2004, September 30th - October 2nd). The roles of writing centers in second language writing instruction. Paper presented at the Second Language Writing Symposium, Purdue University, Illinois.

\section{Author}

Jeremie Seror an associate professor at the Official Languages and Bilingualism Institute at the University of Ottawa. His scholarship focuses on academic discourse socialization in plurilingual and pluricultural settings. His present research projects explore the dynamics and impact of postsecondary immersion programs and second language writing development in digital spaces. Email: jseror@uOttawa.ca

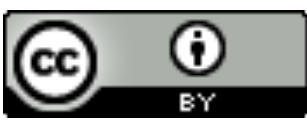

This work is licensed under a Creative Commons Attribution 3.0 License. 